\title{
Udayana University: Proposal for the establishment of a 'Political Parties and Local Governments Studies Center'
}

\author{
Nazrina Zuryani , Muhammad Ali Azhar and Tedi Erviantono
}

\author{
Faculty of Social and Political Sciences, Udayana University, Sudirman Campus, \\ Denpasar, Indonesia \\ e-mails:nazrinazuryani@unud.ac.id, aliazhar23mr@yahoo.co.id and erviantono2@gmail.com
}

\begin{abstract}
In Bali, where political life is largely determined by tradition and the role of Sukarno, the main challenge is to create a cadre system unrelated to mass organizations (gangs), to oligarchy links and to traditional networks (puri/local rulers and Sukarno affiliations). To coin Riswandha Imawan's words, there is "cadre confusion" in that the existing cadres tend not to hee d the goals of the 1998 Movement: they neglect their working duties, fail to pay taxes and do not care about political education -all things mandatory in a democracy. Aware of these failings, Academics from FISIP Udayana University, later supported by colleagues from Warmadewa University and the University of National Education, and by AIPI Bali and several women NGOs, proposed to set up a center for political parties and local Government, which would work with Udayana University's revitalized Tax Center (different from the website Imissu at Udayana University information technology service). In the hope of getting support from the political parties cadres, the FISIP Udayana undertook a series of Focus Group Discussions of cadres followed by a survey. But the cadres refused the 'political clinic' proposed by FISIP as part of the project implementation. A new solution is now put forward by the research team: through the IbIKK (Ipteks bagi Inovatif Kreativitas Kampus), the FISIP Udayana simply proposes to revitalize the Tax Center and to Establish a Political Parties and Local Government Studies Center annexed to the Institute for Peace and Democracy/IPD at Udayana University in Denpasar.
\end{abstract}

Keywords: Center for political parties and local government studies, democracy laboratory, IbIKK, taxation center

\section{INTRODUCTION}

In mid-April 2017, researchers from the Faculty of Social and Political Sciences/FISIP Udayana University set up a cooperation with AIPI Bali Branch with the purpose of establishing a political party clinic in Denpasar. This endeavor followed consultations held with Gadjah Mada members of AIPI Jakarta and were approved by the August 2017 AIPI National Seminar. To gain broader acknowledgment, a Focus Group Discussion/FGD was held at the initiative of FISIP UNUD at Warmadewa University, with the collaboration of the latter university, also with the National Education University, and from the NGO Bali Sruti. Unexpectedly, of the 7 cadres who participated in the focus group discussion (from 11 originally invited), none of them gave their approval to the party clinic idea. Even though civil society at large complains about the lack of accountability and poor transparency of political parties, as well as their wide use of political dowry, these facts were denied by all participants at the FGD.

The academics, eager to establish political party clinics as a means to improve democratic life, were deeply disappointed. On April 202017 focus group discussion (FGD), made clear that, far from supporting the improvement of democratic life, the party cadres actually tended to create obstacles to it.

Faced with the rebuttal above, the researchers did not give up. Supported by a Grant Competence (from Indonesian Higher Degree/Ditbinlitabmas) they undertook to broaden the scope of the survey through the use of a 25 items questionnaire with $\mathrm{A}, \mathrm{B}, \mathrm{C}$ and $\mathrm{D}$ variables) distributed to political cadres by students of the Political Studies Program of Udayana University. The survey results showed that from 61 respondents from 11 political parties, thirty respondents who were political party officials in Denpasar stated that there was no need of a Clinic for Political Parties. The results of both the survey and the FGD clearly indicated that all efforts to establish a Clinic of Political Parties such as suggested by the academics had ended in failure.

The reasons for that failure can be explained as follows. Firstly, there is a difference of perception between the general public and political parties. The aim of a political party clinic is to render the parties more transparent and 
accountable, whereas in their own opinion, the cadres claim that their parties have already achieved the desired transparency and accountability. In their opinion, internal party meetings fulfil the requirements. While, what the public wishes to see are published financial reports, and clear working programs with operational guidelines in accordance with people's needs and expectations.

Secondly, there is a difference comprehend between the views of the general public and political parties related to Financial Management. According to the party cadres, the public should understand that managing political parties is different from managing the company. The difference lies in financial management that in the party financial management prioritizes the things that are strategic rather than prioritizing the procedural, so no matter how much money is not important, the most important is how to run these strategic things. Then funding will be considered after the strategic program is decided to run. While in a company, if there is a project, then the use of money is determined in the planning step before running the project. It is therefore very difficult to audit or evaluate the use of funds in political parties.

Similarly, the function of political cadre regeneration, recruitment and candidature seem dead. According to the cadres, all these functions have been running well. Nevertheless, there is also a small number (from two of the seven political party cadres) who stated that there are still several political parties that have not well performed the functions of regeneration, recruitment, and candidature of party leader.

According to some political party cadres, the demise of these functions is more due to the regulation are currently related to the presidential election. Regulations that allow free fighting systems that used currently running make political parties difficult to perform their functions well. Thus for them, the greatest error is currently in the system or regulation governing political parties and elections practiced by the prevailing government regime.

Obviously, in accountability, the cadres of political parties also need to understand the responsibility of people's money that collected by payment of income taxes, local taxes and other taxes that used by the party arbitrarily as the party machinery in parliament. The leader of the parliament and at the same time the leader of Golongan Karya/functional group party was accused of doing corruption for E-KTP funds throughout Indonesia with a huge amount money. Furthermore, the attitude to do corruption can be seen on two sides of a coin. On one side, it is how importance taxes payment as a sign of democratic attitude of those people's representatives. At another side, to educate people to be more accountable and open mind on the use of money related to job and occupations. In this sense, those political parties cadre felt no guilty of using the money for political campaigns to justify their unaccountable behavior. Secondly, politician job is regarded by many cadres as shopping wheels, such as the case of Hambalang or other corruption cases might be among the example on how those particular politicians in Jakarta play up money projects on account of their unprofessional interests.

This kind of critics should be initiated at universities with courses in Political Science, Governmental Science, State Administration, Sociology, Communication science and International Relations to put forward the content of financial responsibility versus corruption. Failure to understand from party cadres (non-elitist and oligarchic cadres) must be opposed by campus intellectuals. Therefore it is important to understand the rights and obligations of the productive age population of University students in paying taxes as a learning process in being accountable. They are meanwhile understanding the self-transformation side of the Political Parties through its cadres to carry out the function of political education for society as the support of the democratic state. Government funding of political party reform is only one of the 'steps' to the party's selfcorrection which students of social sciences and political science must understand, support and be familiar with as future graduates and leaders in society.

\section{RESEARCH METHODS}

Referring to the FGD and survey results with the three university collaboration systems above, it still shows that the political party has not changed. Since the old regime to the reform era generally politic parties in Indonesia cannot change. By borrowing a term that was once introduced by Gadjah Mada University Scientist, the late Professor Riswandha Imawan (2004) political party in Indonesia always failed to perform self-transformation, they did not want to take the moment to be independent, even let hijacked by elite political oligarchy then appear to controlling the political parties themselves (with hedonistic lifestyles and working comparison by study visits abroad for example).

Another failure is the inconsistency in showing identity as a fighter of public interest. Political parties have always been among the interests and desires to go through stand up as opposition or the elitist-oligarchic mass to be sheltered under the ruling regime. So that, the Political Parties cannot be independent and always under the legislative power, ultimately also be intervened by the executive. This is the fundamental issue ever conveyed by Riswandha Imawan which until now failed to be understood and can never be been done by political parties in Indonesia.

Students and academics who work in the field of social sciences, humanities including political-government science need to learn more deeply the problems of politicians including their lifestyles. Do their tax obligation has been done? What kind of local regulations or Peraturan Daerah/Perda would support democracy, transparency, and accountability would be taken place? How to fix the internal party's intrigues so that the personalization type of elitistoligarchic power can be reduced and disappear if necessary. 
Udayana University in particular Faculty of Social and Political Sciences/FISIP had been planning to give more insight to the students on this political situations by preparing two elective's subjects. By pursuing the students to do an internship at the same time learn from textbooks of 'Population \& Tax' so as 'Political Parties Accountability', it aims at increasing professional competence of the students.

These are the new research methods for educating students in social and political sciences who choose an elective subject in FISIP Unud. Therefore, above- mentioned textbooks need to be read while doing an internship at appointed places that initiated by Faculty of Social and Political Science Udayana University since 2015. Udayana University as an educational institution plan to produce superior, independent and cultured graduates as its goals. They must be first to be aware of the obligation to pay the tax as income tax besides other local taxation such as land and building tax, parking retribution, public lighting taxation, and etcetera.

After the income tax and local taxes are understood, the graduates of social science and political science must also be able to analyze the contemporary democratic conditions. Students and graduates participate in every election and know who has been elected by government regimes through the executive, legislative and judiciary votings according to the principle of democracy who fight for people's interest. In order to run these elective subjects, Udayana University needs to do revitalization of the Tax Center that are not related to the Imissu technology information for the academic service. It is not only a proposal, for educating students at the Political Parties and Local Governments Study Center but becoming a democracy laboratory annexed to Institute Peace and Democracy at Udayana University.

\section{RESULT AND DISCUSSION}

\subsection{Results}

It can be understood that the political party's reluctance to the establishment of the Political Party Clinic by Udayana University in Denpasar and the failure of the party to reform itself is more to the question of whether it will benefit them or not. Because as is commonly known the nature of political parties will pursue power and even accumulate power as much as possible. Such testimony can be felt in the phenomenon of the presence of political parties in various aspects of power via KKN/Kolusi Korupsi and Nepotisme.

Thus, in fact, it can be said that we are currently facing a problem. By borrowing the statement of Abu Hapsin (2016), we are facing an era where the existing political parties are no longer functioning as democratic institutions capable of organizing political education. Elite political parties have lost their idealism. The rise of ethnoreligious based political culture. The political community is now undergoing a transitional period marked by an animistic situation. Politics is still considered a "commander", not a law. Religiousbased political parties seem to have failed to interpret religious symbols and rhetoric into real political life.

Some of the things debated in the current political party for example, the work of our political party today is only based on momentary interest, get closer to the community is only done on a seasonal basis, especially when wanting to gain votes in any elections. The political cadres are strengthened the power of the think-tank group or better known as the elite party adaptive structuring (Giddens 1970, in Heryanto 2015). There is also a phenomenon of political cartelization by elite political parties (Ambardi 2009).

This political reality needs to be analyzed further to the habits of political parties at the local level. There might be no significant difference even at certain levels in relation to the tradition of some regions, this also exacerbates the problems of political parties today. This means that even at the local level there is a tremendous political change of bad habits from political parties that often occur at the national level those are also embedded with bad traditions at the local level.

\subsection{Discussion}

The above statement, as Joel Migdal argues (in Stocker, 2006) states that local political elites are able to utilize and master local decentralization and democracy by placing themselves with their cronies and families in strategic positions to ensure that resource allocation lies in their direction, and grips of local strongmen including gangs and preman. In Bali, this happens since the reformation era where the local political setting in Bali instead of lies in the strength of political parties in nominating candidates for regional leaders in some districts (kota/kabupaten) lies in the power of forces outside political parties. Political forces are taken over by the power of mass organizations or gangsters. Political parties are always behind those forces.

In line with what has been said by Abu Hapsin (2016) above, many years ago Sutoro Eko (2006) in his dissertation "Deepening of local democracy through civil society", has also stated that since the era of reformation, Indonesia experiencing the complicated issue of democracy. The complicated issue, namely the problem of deficit and the vulnerability of democracy since the fall of Soeharto in 1998. Although Indonesia achieved electoral and procedural democracy, more substantive democracies wobbled. The democracy that has been achieved is not managed by the supporters of democracy, but is hijacked by the power of the elite as well as the criminals (AE Priyono, Stanley Adi Prasetyo and Olle Tornquist, 2003).

The biggest issue of political parties besides external capacity is the challenge of strengthening internal capacity. This condition departs from the argument put forward by Handelman and Ethridge (2016: 223) that some political scientists agree on the trend in democracies that is the decline of popular support for political parties in general, with the increasing number of people who identify themselves as an independent group and does not support any political party. The identification of the cause could be the result of a less populist ideological conception, poor organization, lack of funds, poor leadership, unaccountable and corrupt, unethical and fanatic competition, and various other causes (Lawson and Merkl 1988: 3).

Students who study social science and political science must understand the current conditions in the country of Indonesia, namely political parties are running on the process between two sides, one side emphasizes the procedure, legality, and institutional, and the other 
emphasizes the ideal (purpose), meaningfulness and substance (Pabottingi, 2007: xi). The initial response given by one of the authors last March 23, 2017, to deliver socialization of BPK Regulation No. 2 of 2015 on Financial Assistance Political Party must achieve. Activities that certainly strengthening Political Parties that only emphasize aspects of procedures, legality, and institutions.

There is an interesting reality to this activity. When one of the authors offered some solutions in assisting the financial accountability reporting, the cadres denied that regulation. The interest of participants attended showed by some functional of DPC seemed paradoxical with the commitment offered by the Political Parties. At the beginning of the discussion, most of the DPCs felt technical obstacles as regulated by the regulation, such as the categorization of political party assistance to give political education activities (article 1, verse 6); specification of recapitulation of inventory/capital goods (physical), consumable supplies, and use of services (article 8, paragraph 1); as well as disbursement of aid funds that are too close to making accountability reports so that execution of its activities is more constrained in terms of output and outcome. However, when offered the urgency of the Political Parties in responding to these obstacles even if this can be given free of charge, some DPC functionaries still see it as an unurgent thing they need. The role of academics according to some DPC functionaries better contribute in solving political problems at the macro level if possible to help political parties winning the election. Although in fact, it is the main responsibility of the political parties under concerned to gain voters.

Failures of FISIP Udayana University establishing a political party's clinic can be overcome by conducting comparative research of Pemilukada among districts/cities in Indonesia. Research to find the ideological burden of the party with Islamic principles in Bali for example. Also the pattern of family relationship of Puri Agung (kePangeranan) Ubud, Gianyar, Denpasar (Pemecutan, Kesiman, Satria), Buleleng, Karangasem, Bangli, Klungkung, Tabanan, and Negara. Also how it is the look at the governance politician from certain party at the regional level. These research activities can be done through students who work and collaborate with political parties cadre.

When the FGD of FISIP Udayana University was held with Political Parties on April 20, 2017, the issue of cadres was still prominent although they still did not acknowledge explicitly that the issue of human resources of political parties was serious. It is on this condition that can be borrowing Pemberton's terms in Asfar (2005). That is an election by election has taken place seen as merely a democratic ceremonial. As the result of this, most Political Parties see their accountability has completed. Although the indicators set at FGD by academics from 3 universities in Bali stated that every DPD or DPC of Political Parties have and must always be updating their website. In fact, the Political Parties are still unable to fulfill this duty.

Accountability is the demands raised by academics and then accommodated into regulation for the public interest. In addition to that people need thorough information of every politician or political party's cadre at national and local levels. Perhaps with Udayana University revitalizing the Tax Centre with the assistance of Provincial Tax Office of Bali province, the flow of state income and financial donations that go into the treasury of political parties can be any potential study materials of students, lecturers, and the public. Furthermore, through this tax office, a proposal for establishing Political Parties and Local Government Study Centre can be annexed to an existing IPD/Institute Peace and Democracy at Udayana University.

\section{CONCLUSION}

The desire to start the Udayana University Tax Center and run Political Party and Local Government Study Center in Denpasar must certainly see at the local political characteristic of Bali. As noted earlier, adat also plays a central role in local politics, hence this refers slightly to the opinion of the conditions currently underlined by Dwipayana 12 years ago. The strengthening of local and yet personal figures from Puri who will advance in the election of local executive/PILKADA in 2018 and in the year 2019 of legislative election. Academics may be more alert on the strength of certain community organizations than the Political Parties per se.

Any connections with taxation or campaign funds so as money politics must be learned thoroughly. For example in Singaraja during 2016, local taxes for billboards have a deficit. This can be studied further as many mass organizations campaigned was using Baliho and billboards. The strong local men of Baladika, Pemuda Bali Bersatu, and Laskar Bali were among those who advertised themselves through Baliho and Billboards. At the institutional level like at Udayana University, the tax becomes the affairs attached to the regional, sectoral and personal business. None of the political parties cadres see taxation as bounding strategically to the government regime, whereas they are still based on themes related to traditional political institutions, dadia, puri, or adat villages. Political parties as supra-local forces are more likely to be more submissive with the identification of cadre figures to congruent organizations that are congruent with local-level battles, such as competition between castles, clientelistic patterns, inter-dadia rivalitas (Dwipayana, 2005: 98) as well as some of them in relation to the interests / ownership of economic factors capitalistic.

It is just a positive example that becomes the value of compromise for the people of Bali is the character of people who are reluctant to open up conflict and protracted. In Kebayantini's research, Erviantono, et al (2017) conducted with the General Elections Administrator Council (DKPP), shows that potential conflicts, including elections, election, and political party institutions, are avoided as much as possible because of the risk of relationship patterns in their indigenous communities. The reality they avoid is the consequence of adat sanctions where the needs of people living almost $90 \%$ are within the customary village area, such as birth celebrations, marriage to death. Even if there is a prolonged conflict it is believed to be able to have consequences for the karmapala they will be in later, so as far as possible to avoid. On this condition, our analysis of how the presence of political clinics, in the end, is not a major requirement for them (read: Political Parties) to be 
reasonable.

Finally, answering the phrase in this article, will both centers work together and contribute to the improvement of political parties and local government practice? The multiversities or universities in collaboration are namely Udayana University, Warmadewa University and National Education University in Denpasar. It is a demand of academia or scientist who must behave because the task is to provide an explanation of the phenomenon encountered, but still within the specific corridor, measurable and objective. Of course, these academics or scientists should not be held accountable when the results of her/his thoughts turn out to be more harm than good, with reference to the objective and value-free attitude itself.

There is a strengthening of optimism that the initiation of the campus through the proposal of IbIKK (Innovative Science Innovative Creativity Campus) can be another solution to propose. Ditbinlitabmas may see this proposal of the Center for the Study of Political Parties, and the Regional Government is inseparable from criticism, risk and flattery, however, it should still be acceptable. This optimism is at least see political party "a mandate and an important commitment in nominating his best cadres as head of government" at the central and regional levels. This commitment should always be guarded. Academics in many ways often overseeing the capacity building in campus milieu, unfortunately, the campus duty is strengthening graduates of the Faculty of Social and Political Science who are aware of their participation in politics, including paying taxes to run the government at the local level in synergy with the leadership of the state of Indonesia. Multiversities or poli-scale universities through Tax Center need to be revitalized again in order to strengthen the state's finances as a priority for academics and all civitas academica including alumni of Udayana University.

\section{ACKNOWLEDGMENT}

The research team conveys gratitude to DITBINLITABMAS for the competency grant in this final year. Thanks to those who support the writing of this paper. Including good guidance of heads of LPPM, rector and vicerectors of Udayana University, since 2015. Thanks to researchers so as all parties especially the heads of the Regional Office of the Taxation/DJP Bali province, the Bali Provincial KPU and the Election Commission of Denpasar, all institutions that have ever received our students' apprenticeship. To our students, I thank you for drawing the field experience to home your professional competence as well as to be a part of an excellent, independent and cultured alumni.

\section{REFERENCES}

Ambardi, K. (2009). Mengungkap Kartelisasi Partai Politik. Jakarta: KPG, Kepustkaan PopulerGramedia

Asfar, Muhammad. (2005). Mendesain Managemen Pilkada. Surabaya : Pustaka Eureka. ISBN : 9793565-16-0

Dwipayana, AAGN. (2013). Pembiayaan Gotong Royong: Studi tentang dinamika pembiayaan Partai Demokrasi Indonesia-Perjuangan pada periode 1993-1999, Ringkasan Disertasi. Yogyakarta:
Program Parcasarjana Ilmu Politik Universitas Gadjah Mada.

Dwipayana, AAGN. (2001). Kelas dan Kasta: Pergulatan kelas menengah di Bali. Denpasar: Lappera Pustaka.

Eko, S. (2006). Pendalaman Demokrasi Lokal melalui Masyarakat Sipil. Proposal Disertasi, perpustakaan sendiri, belum terpublikasi.

Handelman, Howard \& Ethridge, Marcus E. (2016). Politik dalam Dunia yang Berubah. Bandung : Nusa Media. ISBN. 978-602-72748-6-0

Hapsin A. (2016). The role of political parties in educating democracy (Indonesian experience). Makalah belum dipublikasi

Harriss. Dkk, (2005). Politisasi Demokrasi Politik Lokal Baru.Jakarta: DEMOS

Imawan, R. (2004). Partai Politik di Indonesia: Pergulatan setengah hati mencari jati diri. Pidato pengukuhan sebagai guru besar ilmu Politik, Yogyakarta: Universitas Gadjah Mada, 04 September

Kebayantini, Ni Luh; Erviantono, Tedi, dkk. (2017). Tinjauan Potensi Pelanggaran Penyelenggaraan Pemilu di Bali. Jakarta: DKPP Lawson,

Kay \& Merkl, Peter. (1988). Alternative Organizations : Environmental ], Supplementaru, Communitarian and Authoritarian. NJ:Princenton University Press

Noor, Firman. (2014). Perilaku Politik Pragmatis dalam Kehidupan Politik Kontemporer : Kajian Atas Menurunnya Peran Ideologi Politik di Era Reformasi. Jakarta : LIPI Press. ISSN 0125-9989

Pabottingi, Mochtar. (2007). Partai \& Parlemen Lokal Era Transisi Demokrasi di Indonesia. Jakarta : LIPI Press . ISBN 979-799-052-4

Priyono, dkk. (2003). Gerakan Demokrasi di Indonesia Pasca Suharto, Jakarta: Demos Santoso,

Purwo. (2017). Artikel Demokrasi Terpimpin : Wacana Refleksi Epistemik Menolak Kemandekan. Jurnal PrismaVolume 36, Nomor 01 Tahun 2017. ISSN 0301-6269

West, Richard, and Lynn H. Turner. (2007). Introducing Communication Theory: Analysis and Application. 3rd Edition, McGraw Hill

\section{Internet Sources}

https://nasional.sindonews.com/read/981536/18/diskrepansipelembagaan-Parpol-1427344338 retrieved 27 March 2016

https://nasional.sindonews.com/read/981536/18/diskrepansi -pelembagaan-Parpol-

1427344 
